\title{
Improving Questioning Skill through Application of the Scientific Approach to Children 3-4 Years Old
}

\author{
I Wayan Sutama \\ Early Childhood Education \\ Universitas Negeri Malang \\ Malang, Indonesia \\ wayan.sutama.fip@um.ac.id \\ Leni Gonadi \\ Early Childhood Education \\ Universitas Negeri Malang \\ Malang, Indonesia \\ leni.gonadi.fip@um.ac.id
}

\author{
Sandy Tegariyani Putri Santoso \\ Early Childhood Education \\ Universitas Negeri Malang \\ Malang, Indonesia \\ sandy.tegariyani.fip@um.ac.id \\ Wuri Astuti \\ Early Childhood Education \\ Universitas Negeri Malang \\ Malang, Indonesia \\ wuri.astuti.fip@um.ac.id
}

\begin{abstract}
This study aims to describe the improvement of learning quality and questioning skill through the scientific approach in children aged 3-4 years. The subjects of this study were the children aged 3-4 years in PAUD Tunas Harapan Blitar. This research used classroom action research based of Kemis and Taggart model, including planning, implementation, observation and reflection phase, consisting of 2 cycles. This research used qualitative and quantitative data analysis. The results showed that the application of scientific approach could improve the quality of learning and the ability of the questioning skill in children aged 3-4 years old.
\end{abstract}

Keywords - scientific approach, questioning skill, quality of learning, early childhood

\section{INTRODUCTION}

Early age is a period of progressive growth and continues to spread [1]. Meanwhile, Childford, et al. suggested that early age is a critical period, that is when the individual gets stimulation, treatment or influence from the environment at the right time or at the right time [2]. At this time children form their knowledge through the sensing process so that schemata appear on the child's brain. The more schemata contained in the child's brain, the child will be more intelligent in solving the problems faced by Piaget [3]. Therefore, parents and teachers must facilitate children to interact more with their environment.

One of the characteristics of children during this period of development is a strong curiosity [4]. The curiosity of the child is manifested in the form of asking questions. The child will question everything he observes to the people closest to him through a form of expressive language. The child expresses his curiosity by asking questions. The ability of children to ask questions starts to appear at the age of 18 months to 2 years [5]. At this age, the child is able to ask several questions using the question "what and why." At the age of 3 years, children begin to like asking questions repeatedly.

Ministry of Education and Culture explained that the form of children's ability to express language: able to ask questions, answer questions, communicate orally, and retell what is known [6]. The ability to ask children is classified as expressive language skills because children are expected to be able to convey their curiosity through the delivery of the questions they think or observe. Children are given the opportunity so that children dare to ask questions or question things that are a problem in their daily lives. This is in addition to an expression of curiosity but also a form of critical thinking ability in children.

Based on the description above, it can be concluded that early childhood has a strong curiosity. This curiosity is communicated by the child through questioning sentences. Children have begun to be able to submit simple question sentences with a few question words like "what, where, why, when, who and how". The questioning sent by the child starts from the use of one word, "what", "who" and so on and develop using several words at once, such as "who is it?", "Why the flowers wither?" And so on. Questions raised by children also reflect critical thinking attitudes, for example, "why is this withered and this is not?" And so on. Therefore the teacher needs to give children the opportunity to dare to ask questions about things that are the object of the child's curiousity or if the children question something as a manifestation of their critical thinking abilities.

Language skills (including asking questions) are formed when children interact with and respond to their environment [1]. Therefore the environment has a very significant role in facilitating children in developing language skills, including the ability to ask questions. The teacher can manipulate the environment so that the child is stimulated to speak and ask questions.

Pre-kindergarten students cannot be expected to remain seated for a long period of time. It is not developmentally appropriate to provide worksheets for early childhood students and they will also not learn by listening to a lecture [2]. Students who are 3-5 years old are active explorers of their surroundings. The teacher in early childhood classrooms could be seen as a facilitator of student knowledge as a teacher. The statement also reinforces that children learn more about their environment than working on worksheets or listening to teachers. Children need opportunities to be active in exploring and interacting with their environment. Sudiyah, et al. found that increasing the ability to ask questions through pictorial stories for children aged 4-5 years had a significant increase. This shows that the ability to ask children can be stimulated and improved through manipulation of the child's environment, in this case using media pictorial stories [7]. 
Based on some rational thinking as mentioned above, the researcher tries to improve the ability to ask children through the use of scientific approaches to learning. This is because the child learns constructively and is contextual, through observation of the object or the surrounding environment. Through in-depth observation, the child is expected to have a curiosity about the object of his observation and explore it by asking questions and asking questions of the teacher or his colleagues.

To achieve this purpose, the researcher uses the following method. 1) Children are conditioned to observe an object and provide an opportunity for children to ask questions or question matters related to the object. 2) Children are conditioned to observe the same two objects but under different conditions. 3) Children are conditioned to observe more than two objects that have similarities and differences. These three ways are tried for three meetings and observe the development and tendency of children to ask questions. This is because this approach allows the child to ask (question) something he has observed.

The scientific approach to learning provides steps, ranging from observing a phenomenon, object or other learning material, which is able to stimulate a child's curiosity. In-depth observation will bring up the next activity, namely, the child is given the opportunity to question the things he observes. The question that arises is a strong sense of curiosity about what is observed by the child, which causes them to dig up information by trying, experimenting or other activities that can fulfill their curiosity.

In the next activity, the child is directed to connect what he has known with other related things. The final step is the child can communicate the things he learned [8]. With this experience, children are expected to be brave to express their curiosity freely and comfortably, by stimulating objects around them. Giving children the opportunity to observe an object will allow the child to foster curiosity through questioning everything related to the object he is observing, and different from when the teacher explains the objects seen by the child.

\section{METHOD}

This study used a classroom action research design. This design is used because this study aims to improve the conditions of learning and improve the ability to ask children through a scientific approach. This study used the Kemis and Tagart model, which includes planning, giving action, observation, and reflection [9]. At the time of planning, the researcher conducted an analysis and reflection on the learning situation, especially related to the ability to ask children, and planned actions by making RPPH (lesson plan) using a scientific approach. At the time of action, researchers collaborate with teachers to carry out learning using a scientific approach.

This action-giving activity in cycle 1 was carried out in 3 meetings. The first meeting, the child is invited to observe one object of learning. The meeting of the two children was invited to explore two similar objects but had certain differences. The third meeting, children are invited to explore more than 2 objects. In the observation phase, the researcher observed the learning process and the child's ability to ask questions. This stage is carried out together with the stage of giving the action. The teacher acts as a model teacher, and the researcher is tasked with making observations. Reflection phase, the researcher analyzed the results of meetings 1,2 and 3. The results of the analysis were used as a reference to find strengths and weaknesses in the cycle action 1 . If there were many deficiencies in the first cycle and the success criteria were not met, the researchers analyzed the causes of failure and made the basis for planning the next cycle.

This research was conducted in PAUD Tunas Harapan, Srengat, Blitar. This PAUD institution has a very strategic place and is easily accessible if this program is followed up and supplemented to other PAUD institutions in the vicinity. The subjects of this study were 18 children with an age range between 3-4 years of PAUD Tunas Harapan Blitar.

Data collection techniques used in this study are interviews and observations. The interview technique is used to explore the initial information and the tendency of the child's questioning activities in daily learning. Observation technique is used to collect data about activities and the ability to ask children in learning when the action is carried out. The instrument used to collect data in this study consisted of 1) observation sheet, 2) field notes, and 3) interview guidelines. Observation sheets are used as a reference in observing children's behavior/activities in asking questions. Field notes are used to observe the learning situation when the action is carried out. Interview guidelines are used to guide and direct data collection about conditions before and at the time of action.

The results of the research data were processed with quantitative and qualitative analysis techniques. Quantitative techniques are used to analyze data about the frequency and number of children actively involved in asking. Qualitative analysis is used to analyze data about the quality of learning when an action is taken. The steps of qualitative data analysis include data reduction, data presentation, and conclusion drawing.

\section{RESULT}

\section{A. Cycle I}

Giving action in cycle 1 was carried out 3 meetings. At the first meeting, the teacher used one object to trigger questioning skills through learning based on a scientific approach. The theme explored is plants and vegetable as it sub-themes. At the 2nd meeting, the explored theme is still the plant, with the fruit theme. Whereas at the 3rd meeting, learning explores the theme of plants with flower subthemes.

Based on the observations, the findings are as follows. In the learning activities in the Play Group, PAUD Tunas Harapan everyday uses the center model and applies the 2013 PAUD curriculum. In daily life, learning in PAUD shows the following facts. 1) Teachers have implemented the 2013 PAUD curriculum. 2) The theme chosen is in accordance with the environment around the child, so that the child has the opportunity to explore the environment. 3) Teachers are still the main informants in learning, so children tend to receive information and instructions from the teacher. 4) Interest in children to want to know about an object is still low. 5) The teacher explains more than gives children the opportunity to observe and observe. The impact of these 
conditions is that children's questioning skills are still low, very few children have the initiative to ask questions, the rest of the children only answer questions from the teacher and the child looks confused when asked by the teacher to ask.

The application of an intensive scientific approach to learning in the PAUD Tunas Harapan Play Group turned out to have an impact on the quality of learning. (1) Learning activities have been carried out in accordance with the stages of learning namely initial activities, core, and closing. (2) Learning has given children the opportunity to observe, ask, collect information, reason and communicate. But the opportunity has not been used as well as possible by children. (3) Children prefer listening, answering questions and playing activities that involve a physical motor. Nevertheless, the intensity of children's activity is increasing and children are more enthusiastic in their learning. The application of the scientific approach also turned out to take a relatively long time because it had to provide a real learning experience, and this caused the final activity to be less effective.

In cycle 1 activities, the ability to ask children is still unstable and not optimal, even though they have been given the opportunity to ask questions by the teacher more widely. (1) Children had not been able to take advantage of the opportunity and tends to prefer answering questions rather than asking questions. (2) The only question aroused was about the process of peeling corn and the use of corn kernels. (4) The level of courage to ask children is not too emerging which is likely due to embarrassment at the presence of new people (researchers) when learning activities take place. (5) Courage to ask children begins to appear when instructed to ask the class teacher (instructed to ask). (6) Some children have begun to dare to ask even if they are quiet and shy. (7) Questions that arise during learning are 3 questions. (8) The number of children who ask when learning is 3 children who dare to ask the class teacher. (9) There are some children who whisper to each other and ask friends next to him but when asked by the teacher, the child is silent and just smiles shyly.

In the second meeting, the facts were obtained: (1) the level of courage to ask children actually declined today because the possibility of fruit learning material was common for children. This causes the child not to feel curious about what he sees. (2) The frequency of questions that arise when learning on that day is only 1 question. (3) The number of children who ask when learning is one child on that day. Other children tend to be quiet and only see because of the possibility that the child has already done learning activities on that day. (3) The level/quality of questions that arise in children during learning is included in the types of questions about the processes related to the ways and stages of making guava juice.

At the 3rd meeting shows the following facts. (1) Children have more courage to ask questions to fulfill their curiosity. (2) The frequency of questions that appear on that day was based on 4 questions posed by 3 children. (3) The quality of questions also increases in children, not only factual questions but also increases to questions of understanding and questions about the process (application).

From the aforementioned facts, the child's questioning skills still seem unstable. This is influenced by the learning object presented by the teacher. Besides that, the teacher also seems not optimal in stimulating children to ask questions and tends to be trapped by asking their own questions to children. This can cause the child to be passive in asking.

The results of reflection in cycle 1 show the following points. (1) Learning has become more effective, as evidenced by learning that has applied the principles of the 2013 curriculum, namely learning that uses thematic and scientific approaches. Children become active in learning through play, which prioritizes children's direct experience. (2) The child's courage to ask is still lacking; (3) The number of questions that appear is still small. (3) The level of question quality is still low, which is limited to factual, understanding and application questions.

Follow-up plan, that is by making a more contextual learning plan. Children are given direct experience and learning practices that are more meaningful in the rules of applying thematic and scientific learning. Children are invited to explore directly the objects of learning and if possible the child is invited to learn to the original source.

\section{B. Cycle 2}

After improvements in learning planning, the learning process in cycle 2 becomes better. Children are more enthusiastic about participating in activities. Findings in the core activity process at meeting 1 cycle 2 showed that children were very enthusiastic and enthusiastic when participating in learning activities. Almost all children are actively involved in today's activities. Children freely ask questions related to the process of making 'gethuk'. Learning is fun and more democratic.

Findings in the core activity process at the 2 nd cycle 2 meeting showed that children were enthusiastic and enthusiastic when participating in learning activities. The learning atmosphere is very conducive and provides opportunities for more and more questions to arise in children. Findings in the core activity process at the 3rd cycle 2 meeting show that children are enthusiastic and enthusiastic when participating in learning activities. Learning activities run fun and encourage children to be active because their activities are challenging for children.

Based on the three findings in each of the core activities, there was an increase in the quality of learning. Learning becomes conducive, more and more provides opportunities for children to observe, ask, and try through learning based on scientific approaches. Evaluating the questioning skill of children, in cycle 2 began to show improvement. Similarly, the number of children asking questions and the types and number of questions is increasing.

Findings on children's questioning skills are as follows. (a) The number of children who asked in the second cycle of meeting 1 there were 4 children with 46 questions. (b) The number of questions that appear in cycle 2 of meeting 2 is 79. (c) The number of questions that appear in cycle 2 of meeting 2 is 79 . The number of questions that appear is 33 . (b) Number of children who ask 9 children. This shows that the use of scientific approaches and the use of objects or objects of learning that are right will make children challenged to ask questions.

From these findings, a temporary conclusion can be made that the use of a scientific approach to learning in PAUD can improve the quality of learning and cause children to be 
enthusiastic about asking. The more interesting and challenging learning, the higher the interest of the child to know something that is reflected in the questions posed by the child. Based on the results of research achieved in cycle 2 , reflection can be done as follows. (1) Application of a scientific approach to learning and the use of learning objects that can directly improve the quality of learning. Children become active, learning becomes conducive and democratic. This means that the use of a scientific approach can improve the quality of learning in PAUD. (2) The application of the scientific approach can provide opportunities for children to ask questions or question what they encounter, face or learn. (3) The number of children who ask is still in optimal learning. This is because the culture of asking children is still lacking and teachers who are still dominant ask questions. (4) The type of children's questions are still lacking, this is because in addition to the level of child development is still in the preoperational stage, is imaginative and not used to questioning something. (5) The quality of children's questions is still dominant in factual questions.

\section{DISCUSSION}

\section{A. Learning Quality Improvement through the Application of the Scientific Approach}

The results of this study indicate that the application of a scientific approach can improve the quality of learning. This is because the scientific approach children are accustomed to observing objects of learning directly. Intensive observation of learning objects will stimulate children to arouse their curiosity [10]. One way to express a child's curiosity is to ask. This is also consistent with the opinion of Buysse and Wesley that children have a natural curiosity and the teacher should encourage children to fulfill their curiosity through the discovery process [11].

It is proven that through the application of the scientific approach, children are active from the beginning of the activity. Children have an enthusiasm when dealing with learning objects directly (CTL.1.1.2), (TS.1.2.1). By applying the scientific approach in learning at PAUD Tunas Harapan Blitar, children have had the opportunity to observe, ask questions, gather information or try (KS.1.1.1, 1.1.2, 1.1.3, TS.2.1.2, TS .2.2.3).

The application of the scientific approach at PAUD Tunas Harapan also causes the learning situation to be more conducive and democratic. This can be seen from the enthusiasm of children to participate in learning activities and the teacher provides ample opportunities for questions arising from children (CTL.2.2.3). Learning is said to be more democratic because children are given the opportunity to share their ideas when determining the rules of play/activities (CTL.2.3.1 and TS.2.3.1).

\section{B. Questioning skills Improvement through the Application of the Scientific Approach}

The application of the scientific approach to learning was able to improve children's questioning skills. Questioning skills need to be developed in children because this is one form of expressive language mastery in children [5]. Although in cycle 1, children's questioning skills have not yet emerged significantly but entered cycle 2 , children are increasingly brave to ask questions.
It can be seen that in cycle 2 meeting 1 the number of children who asked 4 children with a total of 46 questions (CTL.2.1.4), increased at the second meeting as many as 7 children with a total of 79 questions (CTL.2.2.5) At the 3rd meeting, the number of children who asked increased to 9 children with a total of 33 questions (CTL.2.3.4). Although the number of questions that arise is not stable, the tendency of courage and questioning skills of children tends to increase.

It's just that, when viewed from the quality of the questions that arise in children, most are still questions that are factual (lower order thinking). This is understandable because (1) changing the learning mindset from teachercentered to child-centered learning requires a long time. (2) For PAUD, the focus is on how children are used to daring to question something rather than children accustomed to answering teacher questions. (3) The stage of thinking of children is still at the preoperational stage which is more dominated by imaginative thinking skills [12]. What should appear a lot is imaginative questions to bring creativity. But because children are accustomed to answering questions and are not used to questioning something, this certainly requires habituation to children.

\section{CONCLUSION}

Based on the results of the study can be concluded as follows. (1) The application of a scientific approach can improve the quality of learning. This is evident from the increasing level of children's involvement in learning, the level of children's learning atmosphere that is effective, fun, democratic and creative. (2) The application of the scientific approach to learning can improve questioning skills in early childhood. This is evident from the level of courage to ask children when learning is increasing, the number of questions that arise tends to increase and the quality of children's questions also tends to increase.

Based on the results of the research above, it can be suggested as follows. First, PAUD institutions should deepen their understanding of the 2013 curriculum, especially in planning and implementing learning based on a scientific approach. This is to change the learning mindset from teacher-centered to student-centered learning, and from partial learning to meaningful learning. Second, although there appears to be an increase in children's questioning skills through the application of scientific approaches to learning, the level of questions and the frequency of the number of children who ask are still not optimal. This requires further research so that the child is more than just asking, but questioning something so that it can improve critical thinking and creative skills.

\section{REFERENCES}

[1] C. Seefeldt, and B. Nita. Early Childhood Education, an Introduction. New York: Macmillan. 1994.

[2] R. M. Clifford, O. Barbarin, F. Chang, D. Early, D. Bryant, C. Howes, M. Burchinal, and R. Pianta, "What is pre-kindergarten? Characteristics of public pre-kindergarten programs," in Applied Developmental Science," vol. 9(3), 2005, pp. 126-43.

[3] I. W. Sutama, 2016. Kemampuan Guru dalam Melaksanakan Pembelajaran Berbasis Pendekatan Saintifik di TK se Kecamatan Tumpang, Malang. Laporan Penelitian. Malang: Fakultas Ilmu Pendidikan, Universitas Negeri Malang.

[4] T. Bruce, Early childhood education. Hachette UK, 2012. 
[5] N. A. Wiyanti, Psikologi Perkembangan Anak Usia Dini. Yogyakarta: Gava Media. 2014.

[6] Kemendikbud. Kerangka Dasar Dan Struktur Kurikulum 2013 Pendidikan Anak Usia Dini. Jakarta: Direktorat Jenderal Pendidikan Anak Usia Dini Dan Pendidikan Masyarakat Direktorat Pembinaan Pendidikan Anak Usia Dini. 2015.

[7] S. Sudiyah and R. Marmawi, "Peningkatan Aktivitas Bertanya Melalui Cerita Bergambar Pada Anak Usia 4-5 Tahun," in Jurnal Pendidikan dan Pembelajaran, vol. 3(10).

[8] Permendikbud No. 146 Tahun 2014, tentang Kurikulum 2013 PAUD. 2014.
[9] S. Kemmis and M. R. Taggart. The Action Research Planner. Geelong, Australia. 2002.

[10] W. S. Barnett. "Early childhood education. School reform proposals: The research evidence," vol. 2002 Apr 1, pp.1-26.

[11] V. Buysse and P. W. Wesley. Consultation in early childhood settings. Paul H. Brookes Pub., 2005.

[12] I. W. Sutama, Implementasi Pendekatan Saintifik Dalam Konteks Pembelajaran Berbasis Sosial Budaya Untuk Anak Usia Dini. Artikel dimuat dalam Prosiding FIP, JIP Gorontalo, 2015. 